\title{
EFFECTIVE FACTORS IN CHILDREN'S SPECIALIZED HOSPITAL DESIGNING TO DECREASE STRESS (CASES STUDY: IMAM HOSSEIN CHILDREN'S SPECIALIZED HOSPITAL, PEDIATRICS DEPARTMENT OF DR.GHARAZI, ASGARIYE AND SHAFA HOSPITALS)
}

\author{
Engineer Zahra Amirazodi \\ M.Arch Student, University of Kashan \\ z_amirazodi@yahoo.com \\ Dr. Javad Divandari \\ Assistant Professor, Architecture Department, University of Kashan \\ jdivandari@kashanu.ac.ir \\ Dr. Ahmad Danaeinia \\ Assistant Professor, Architecture Department, University of Kashan \\ danaeinia@kashanu.ac.ir \\ Dr. Fariborz Sedighi Arfaee \\ Associate Professor, Psychological Department, University of Kashan \\ arfaee@kashanu.ac.ir
}

\begin{abstract}
Therapeutic environment is such environments that affects children's psychological states, inappropriate designing of these environments can increase behavioral disorders. Due to the current status in children's hospital in Iran, there are some problems including facilities and appropriate environment shortage, inattention to children's needs and moods and influence of environment on physical and psychological conditions of sick children. These issues can cause to increase fear, boarding, hospitalization and treatment process. This study is library research and it has been conducted using the results of questionnaires which were fulfilled by 20 sick children in 4 hospitals in Esfahan and mixed (quantitative and qualitative) and analytical method. The results showed that needs of children are divided into two categories: 1) physical environment. 2) Psychological environment. The researchers have presented special solutions for children's therapeutic environments by paying attention to these needs and using obtained solutions from previous studies about solving the problems in children's therapeutic environments. These solutions make desirable environment to decrease stress during hospitalization.
\end{abstract}

Keywords: child, hospital environment, children's needs, stress

\section{INTRODUCTION}

Therapeutic environment is such environments that affects children's psychological states. As a result of different illnesses, children need special cares for treatment. Sensitive mood of children during illness, passing treatment process and bear the pain make them so stressful. In addition to these stresses, additional stresses as a result of interaction between human and environment affect child and cause more problems. Therapeutic places should be in such way that responses to their physical and psychological needs and decrees stress. Right reaction to these needs and patients' expectations is an important role of 
healthcare institutions. Inappropriate designing of these places can cause to increase fear, anxiety and behavioral disorders. This study investigates relations between child's physical and psychological needs and hospital designing to decrease stress in children hospitals.

\section{OBJECTIVES OF THE STUDY}

- Investigation of children's needs and interests for finding solutions to make desirable environment and decrease sick children's stress

- To increase satisfaction of hospital environment using environment psychological principles in treatment process.

- Achieve to the list of needs to guide designers of healthcare institutes for presenting medical facilities and qualitative improvement to satisfy patients and their relatives.

\section{METHODOLOGY}

Present study has been conducted by mixed (quantitative and qualitative) and analytical method. At first the researchers used written resources in the library, document center and research websites and analyzed information about challenges to children's treatment. Then the researchers visited 4 hospitals (Imam Hossein Children's Specialized Hospital, pediatrics department of Dr.Gharazi, Asgariye and Shafa hospitals) and asked 20 children (4 to 12 age) to fulfill the questionnaires.

\section{LITERATURE REVIEW}

Florence Nightingale, in the late 1800 s was one of the first people who studied effective environmental factors to improve healing and decrease stress in hospitals and suggested higher hospitalization rooms with bigger windows and natural lights. After his suggestion, in the middle of 1970s, some researchers discussed about these kinds of buildings specially children's therapeutic environment and stated that the corridors without window and meandrous, sterilized environment with bad smell make unpleasant feeling and cause to stress. Academically, since 1980 Dr. Roger Ulrich investigated about influence of interior design on healthiness and stated this in some researches specially. Jun tai in the research entitled " playing in hospital", studied importance of playing for treatment, impact of this on stress reducing and designed some playing places in hospital. Then to know comments of children about hospitalization, a research using stated stories by children was done. The population of this research were someone who presented in hospital and someone who never hospitalized. The children mentioned about fear and stress during hospitalization more and more. Also, Wilson et al did do a research same as this and faced with same results (Hojjat, Ebneshahidi, 2011). Also, Lider, Bill and Santes stated that physical environment of hospital can cause to stress by negative transferring of concepts. Koperso knew familiarity with hospital as an important factor to make stress. Also, lack of some places for playing and communication with other hospitalized children are other stressful factors (Ghorbani, Enayati, 2015).

\section{THEORETICAL FRAMEWORK}

\section{Child's Stress in Therapeutic Environment}

Stress is a phenomenon that causes reactive changes and affects calmness. This is appeared when person meets social, physical or physiological motivations. The children express stress rarely, but it does not mean they do not feel stress. In compare to adults, children show more violent reactions during stress and experience strange behaviors (Kahana, 2003, p.119). Child is curious and looks at world from childish view, but this view is not as complex as adult people (Balayan, 1991, p.110). The child does not understand something that were experienced, so misinterpretation is happened. Fears can be seen in different ways (Shmitt and ...2001, p. 20). Common stress during childhood is sickness and hospitalization. The sick child needs repetitive or long term hospitalization; so go away form a familiar place, go to an unfamiliar place with different rules, behaviors and faces with unfamiliar people which can affect child negatively (Del Nord 2006, p.291). Professor Dilani stated that physical environment affects behavior and negatively or positively experience of one place can be affective in making stress or 
overcoming stress (Dilani, 2000). So, just mentioning of hospital name can cause negative exciting reactions such as anxiety or fear. Looking at hospital environments (in all shapes and dimensions) can be terrible for child, so the hospital is described as a strange, incomprehensible, unfamiliar and scary place and they are related to such treatment which caused these concepts. Hospitalized children feel themselves in a big exciting weakness and effects of hospitalization and being away from home are more difficult than sickness and treatment (Del Nord, 2006, p.297). On the basis of profitableness category which was defined by Edelmann, clearly anxiety and distress are distinguishable from anxiety which was made as a result of hospitalization and seeing building of the hospital (Del Nord, 2006, p.298). Undoubtedly, organizational and technological appearance of the hospital, the hospitalization environment, limitation of freedom and selection and obedience message cause sickness of child (De Vos, 2006). The child is familiar only with home, school or kindergarten, so it causes unfamiliarity and incomprehension with hospital. Lack of a place for playing or communication with other hospitalized children can cause stress (Del Nord, 2006, p.297). Psychic hospitalism is defined as stressful motivations which are made in hospital. It is divided into two categories: 1) the motivations which are related to sickness and kind of treatment 2) the motivation which are made as a result of being in an unfamiliar place and treatment by unfamiliar persons (Del Nord 2006, p.299). In this research, it is clear that how hospitalization can be harmful which is result of taking distance from familiar childhood world and the child considers this event as an unfair punishment (Hojjat, Ebneshahidi, 2011).

\section{Study of Effective Factors in Child's Stress Increasing in Hospital}

Looking at medical equipment in hospitalization room: vision is the main sense from five senses, collects data more than other senses and transfers them to the brain (Barati 2011).

Taking distance from family and positive social interactions: naturally, human need communication; so if the patients keep in touch with their family, they can feel less stress and feel better in a short time (Ulrich, 1889).

Bewilderment in environment: is one of stressful factors. If somebody wants to find the destination hastily and cannot find it, sickness will be appeared and stress will be increased.

Understanding the environment is too important to clarify the destinations. Human relies on two different perceptual systems for clarifying destination in environment: visual analogy and kinetic sense. Kinetic sense cannot understand anything in weightlessness condition and only visual analogy can clarify direction, so one base point is needed. Both of them are used to navigate, user is considered in hypothetical coordinate system and location of the user is evaluated based on this coordinate (Pakzad, 2012, p.97).

Crowd and noise: listening is an important tool to receive environment information. Quality and quantity of environment noise affect environment quality. Kind and quantity of tolerable noises are different in different kinds of environment and our expectations (Pakzad, 2012, p.78).

Sometimes noise makes person accustom to the place and creates an index factor in the environment (Pakzad, 2012, p.85).

Presence in unfamiliar environment: hospital is a place that the patients face with different environment from their home. The patients cannot feel cordiality such as home as a result of different rules, decoration and other aspects of hospital and they cannot have their favorites which causes worry.

\section{Results of Filed Study}

According to physical and structural needs of children's healthcare environments, the researchers visited 4 hospitals (Imam Hossein Children's Specialized Hospital, pediatrics department of Dr.Gharazi, Asgariye and Shafa hospitals), prepared primary open questionnaires after interview with responsible persons and nurses and visiting different parts of hospital. The final questionnaires were prepared after making changes, completion and validation and then 20 children were fulfilled them.

1. When the doctor permits you to do something, what is your preference?

Submit Date: 01.05.2016, Acceptance Date: 20.06.2016, DOI NO: 10.7456/1060JSE/061 Copyright (C) The Turkish Online Journal of Design, Art and Communication 
The Turkish Online Journal of Design, Art and Communication - TOJDAC July 2016 Special Edition

Playing $\square \quad$ Rest $\square \quad$ Painting $\square \quad$ watching movie $\square$

2. Where is your preference to play?

Playing room $\square$ Outdoor $\square$ Hospitalization room $\square$ Hospitalization room of your friends $\square$

3. Which design is suitable for hospitalization room?

Floral $\square \quad$ simple $\square \quad$ cartoon design $\square \quad$ shaped design $\square$

4. Which is suitable shape of windows in hospitalization room?

Small square $\square \quad$ big square $\square \quad$ curve $\square \quad$ different shapes $\square$

5. Who do you want to accompany you at night?

Mother $\square \quad$ father $\square \quad$ all members of family $\square \quad$ your hospital friends $\square$

6. Presence of whom makes you calm during medical process (serum, bodily injection ...)?

Mother and father $\square$ all members of family $\square \quad$ your hospital friends $\square \quad$ doctor and nurse

7. In presence of whom you can feel better?

Mother $\square \quad$ father $\square \quad$ all members of family $\square \quad$ your hospital friends $\square$

8. Who are your preference to play?

Family $\square \quad$ your hospital friends $\square \quad$ nurse $\square \quad$ alone $\square$ 
According to mentioned questions and obtained answered, needs of children are divided into two categories (figure 1).

the obtained needs form questionnariares whichwere fulfiiled by children

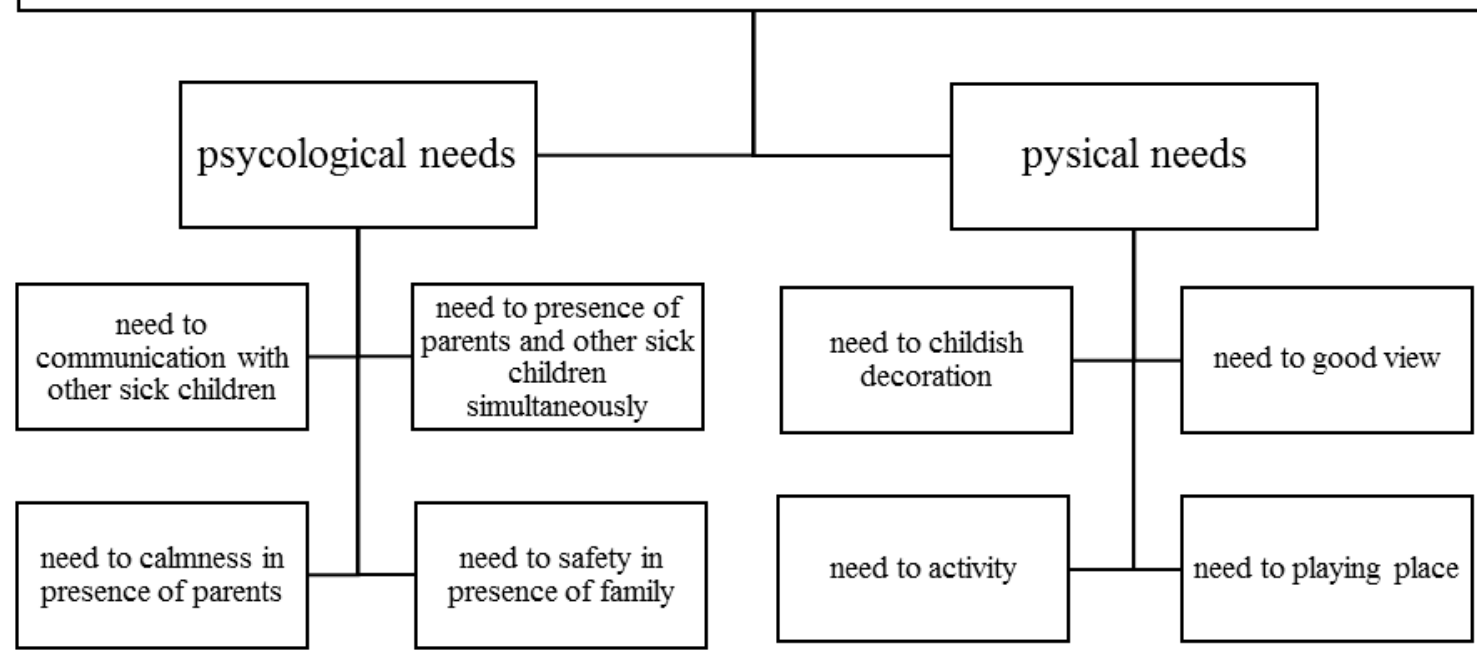

Figure 1: children's needs according to fulfilled questionnaires (Authors)

\subsection{Physical Needs}

A) Need to activity: the results of question 1 showed in figures 2 and 3
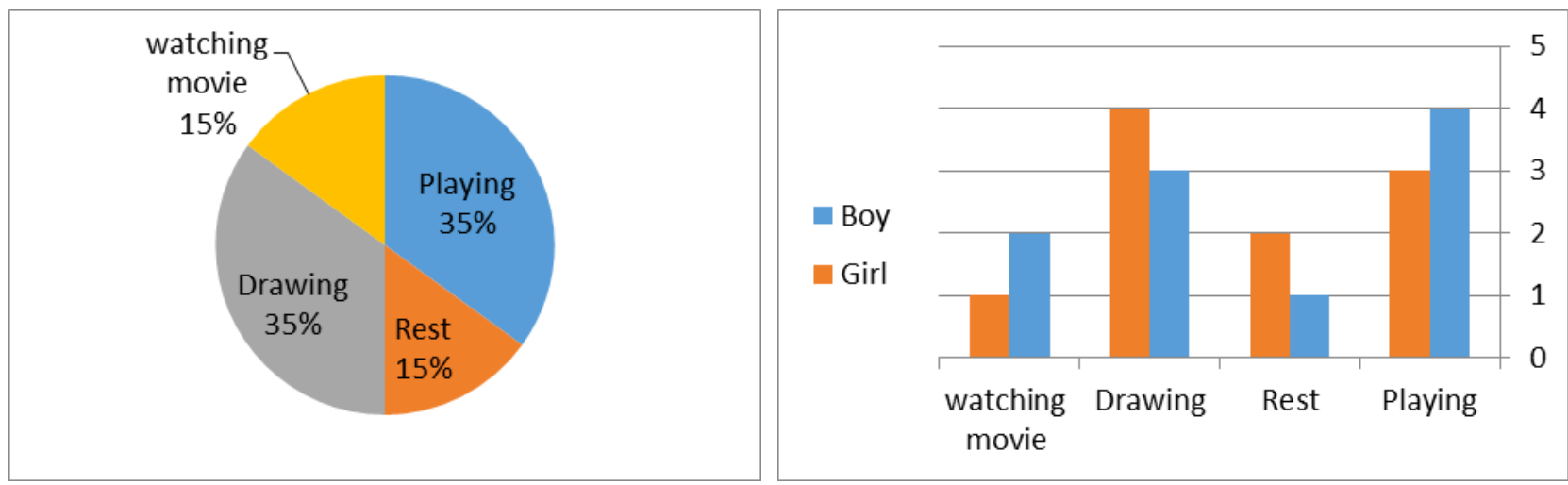

Figure 2 and 3: results of questionnaire (Authors) 
According to the results, the first preferences for children are playing and drawing (35\%). The girls wanted to draw and the boys wanted to play and then they needed relaxation and watching movies (10\%). The girls preferred relaxation and the boy wanted to watch movies.

B) Need to playing place: the results of question 2 were shown in figures 4 and 5

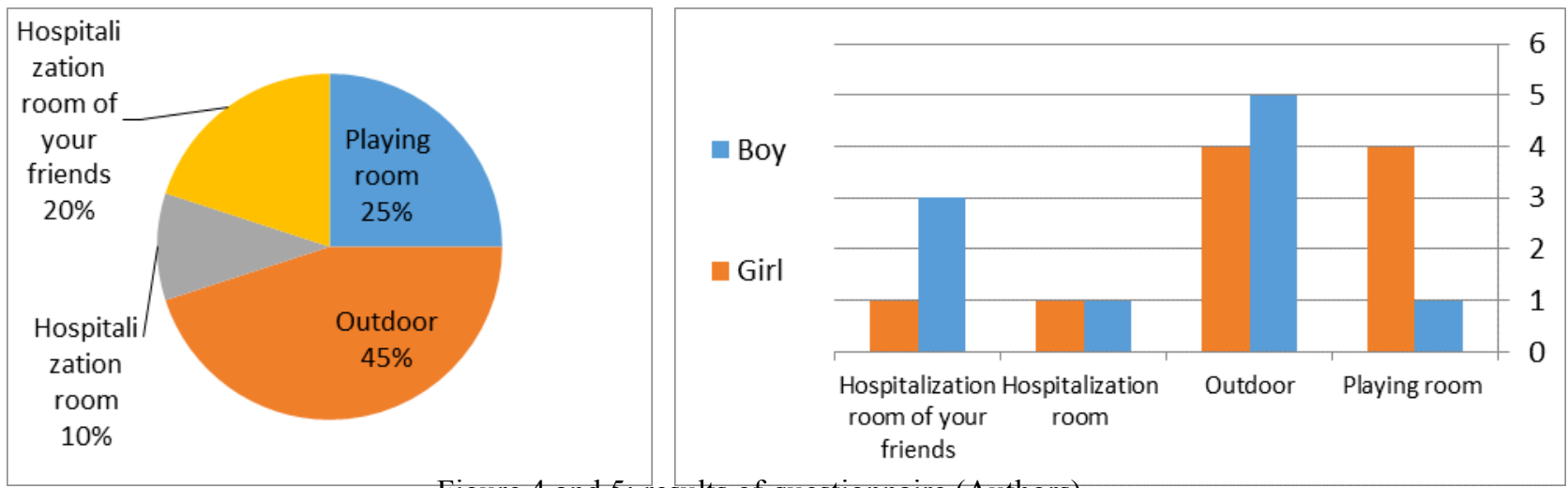

Figure 4 and 5: results of questionnaire (Authors)

Based on the results, the first preference of children is playing outdoor (45\%) which is seen in the boy group. Then they wanted to play in playing room $(25 \%)$, this is the preference for the girls. Next one is playing in other children's rooms (20\%) (Preference of boys).Finally, some children wanted to play in their rooms $(10 \%)$.

C) Need to childish decoration: the results of question 3 were shown in figures 6 and 7

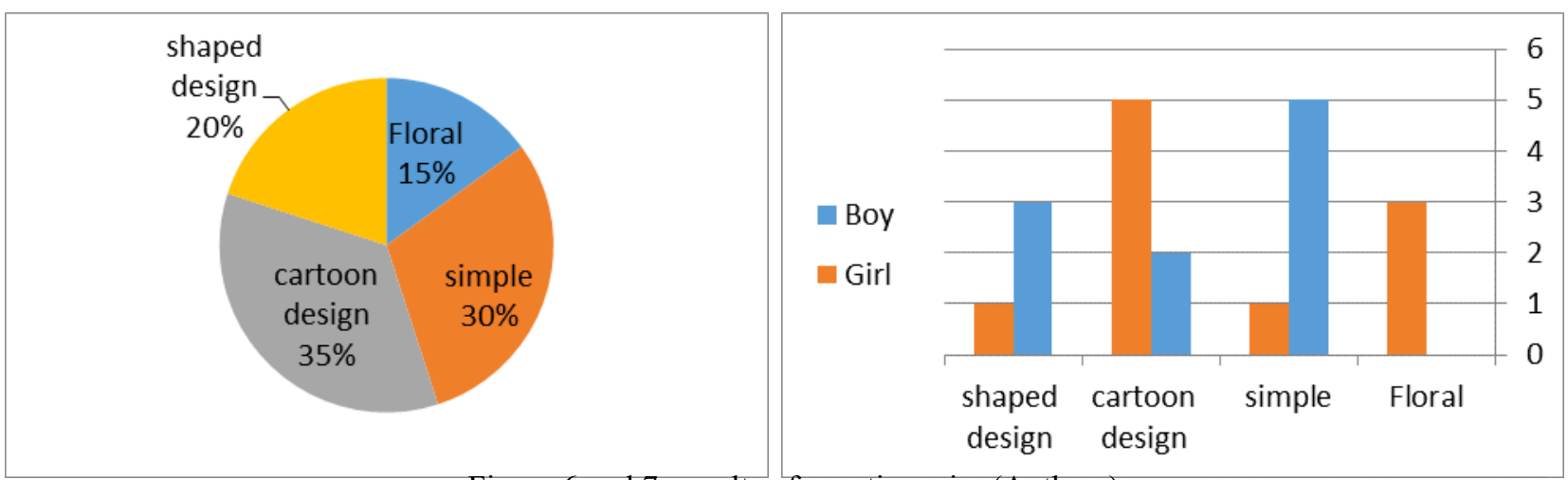

Figure 6 and 7: results of questionnaire (Authors)

The girls interested in cartoon design and the boy wanted simple design. After these, the girls preferred floral and the boys wanted shaped designed.

D) Need to good view: the results of question 4 were shown in figures 8 and 9

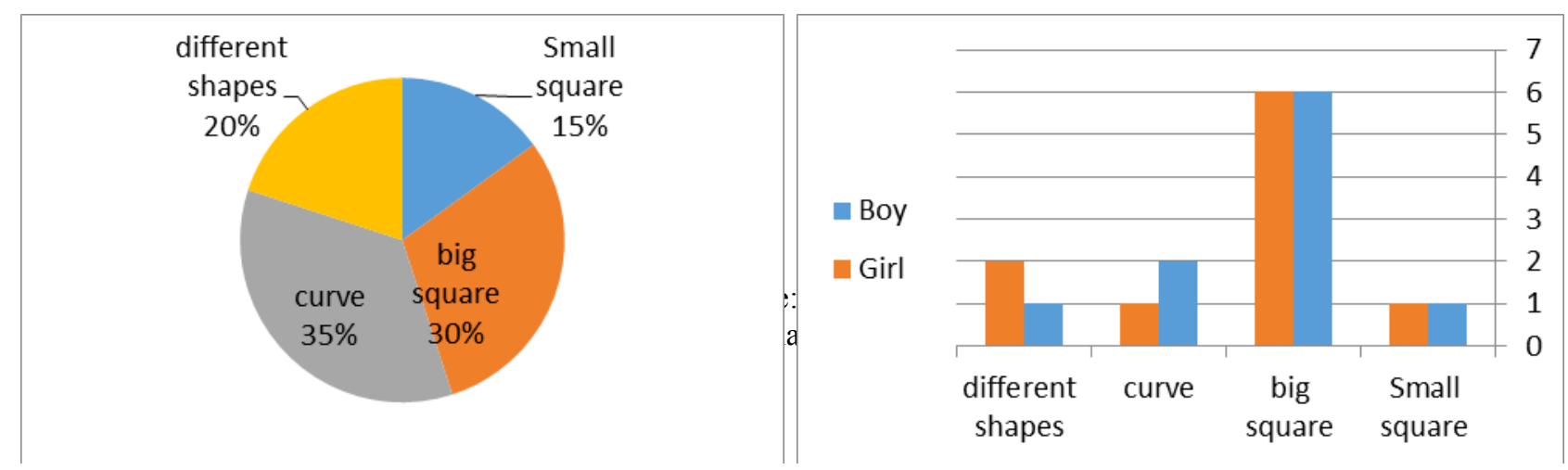


Figure 8 and 9: results of questionnaire (Authors)

Big square windows were attractive for children $(60 \%)$, then small or curve windows were wanted (15\%). Some of children preferred different shapes windows $(10 \%)$.

\subsection{Psychological Needs}

A) Need to safety in presence of family during relaxation: the results of question 5 were shown in figures 10 and 11

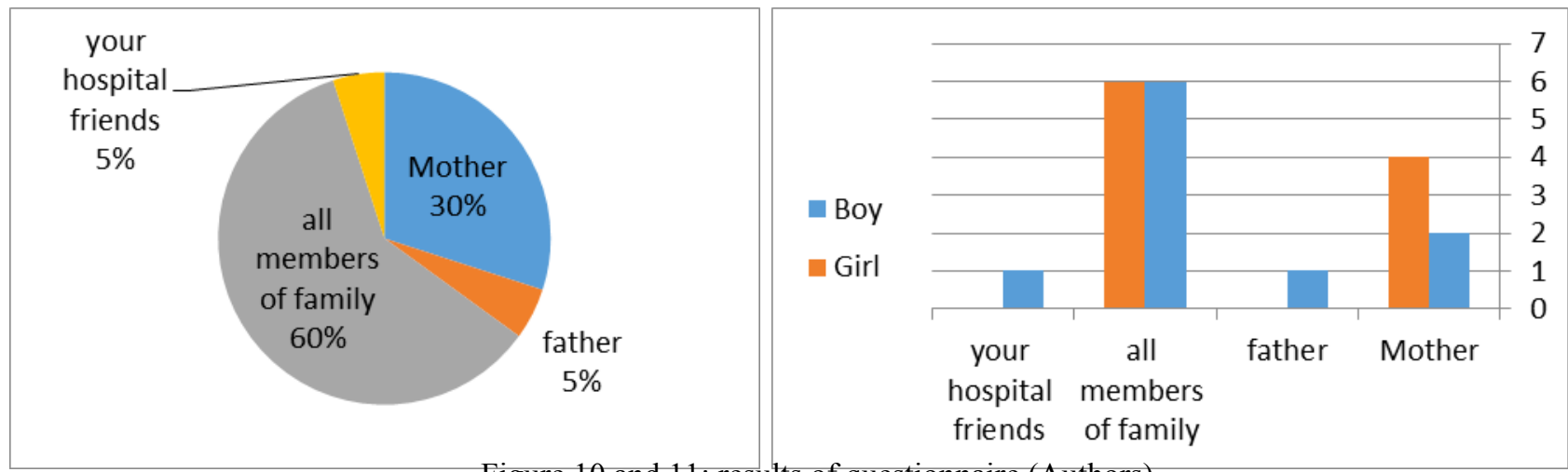

Figure 10 and 11: results of questionnaire (Authors)

$60 \%$ of the child needed all members of family at night and $30 \%$ needed their mothers who were girls.

B) Need to calmness in presence of parents: the results of question 6 were shown in figures 12 and 13

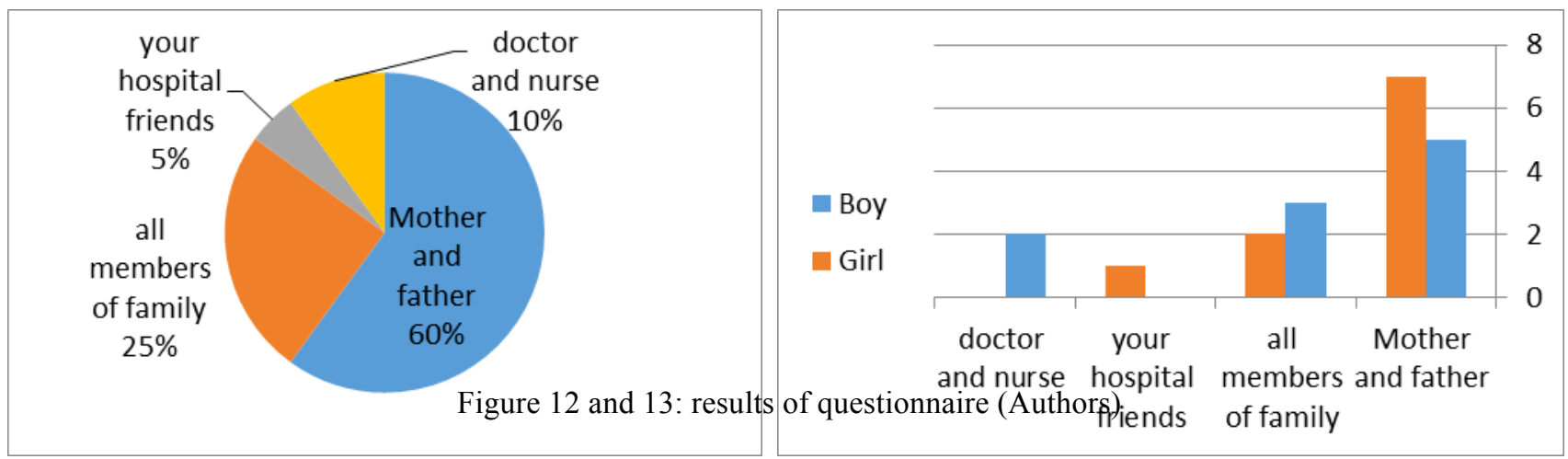

The children needed their parents during medical process $(60 \%)$. Some of the children needed all members of family (25\%). Some boys preferred aloneness $(10 \%)$ and some girls wanted their hospitalized friends $(5 \%)$. 
C) Need to presence of parents and other sick children: the results of question 7 were shown in figures 14 and 15

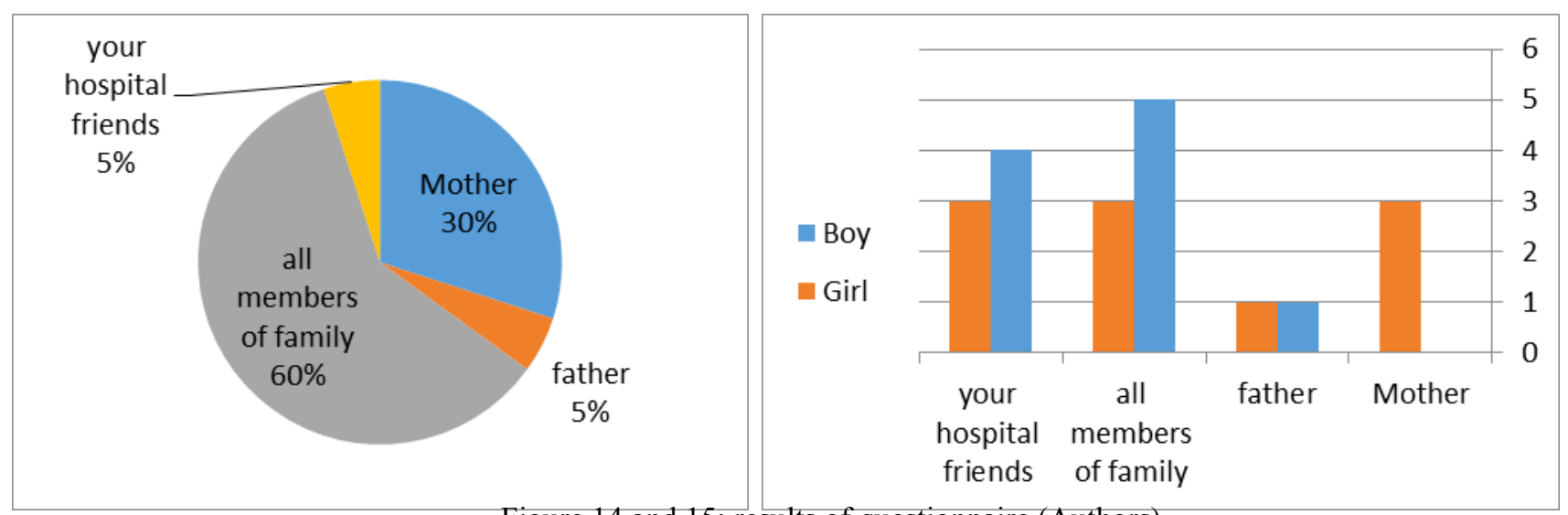

Figure 14 and 15: results of questionnaire (Authors)

$40 \%$ of the children wanted their family and $35 \%$ wanted other children. The girls needed their mothers $(15 \%)$ and some other children needed their fathers $(10 \%)$.

D) Need to presence of other sick children: the results of question 8 were shown in figures 516 and 17

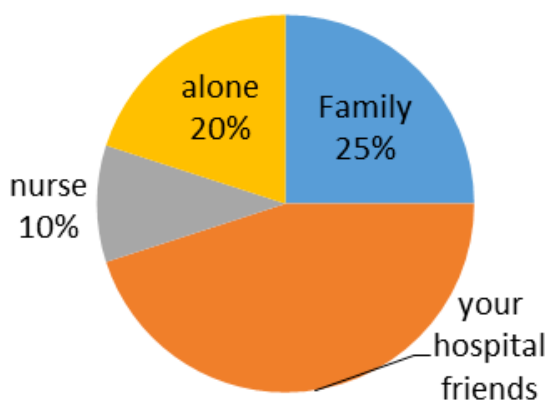

Figure 165and 17: results of questionnaire (Authors)

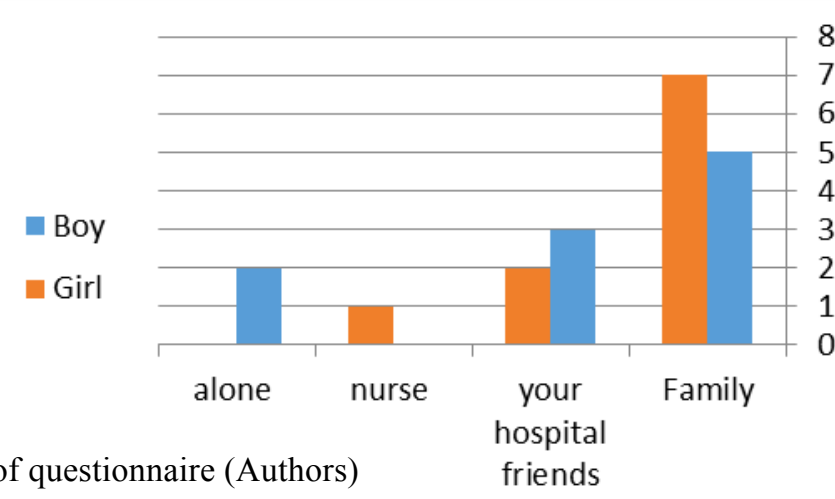

$50 \%$ of children wanted to play with other hospitalized children, $25 \%$ needed their family, $20 \%$ preferred playing alone and 5\% wanted to play with nurses.

\section{CONCLUSION}

As it was mentioned, hospital should be well designed to response to children's needs and decrease fear. Based on the results and combing them with obtained data from previous researches about therapeutic environment, some solutions have been presented to optimize the condition which have been stated in table 1 . 
Table 1: results of the study (Authors)

\begin{tabular}{|c|c|c|}
\hline Filed study & Library study & Solution \\
\hline need to activity & $\begin{array}{l}\text { Build a place for playing in } \\
\text { hospital }\end{array}$ & $\begin{array}{l}\text { Design a room including television } \\
\text { and some tables to do intellectual } \\
\text { activities, drawing and handiwork }\end{array}$ \\
\hline need to playing place & $\begin{array}{l}\text { Build a place for playing in } \\
\text { hospital }\end{array}$ & $\begin{array}{l}\text { Design playing room and a place for } \\
\text { playing outdoor, beds with playing } \\
\text { environment (it means that a bed that } \\
\text { is near to toys). }\end{array}$ \\
\hline need to childish decoration & $\begin{array}{l}\text { Environment variety and } \\
\text { attractive activities, } \\
\text { appropriate decoration for } \\
\text { children, using colorful } \\
\text { designs }\end{array}$ & $\begin{array}{l}\text { Using appropriate shapes on the wall, } \\
\text { corridors and margin of the ceil, } \\
\text { different colors in different places, } \\
\text { writing number on the floor }\end{array}$ \\
\hline $\begin{array}{l}\text { need to calmness in presence } \\
\text { of family }\end{array}$ & $\begin{array}{l}\text { Make some facilities to } \\
\text { presence of parents in } \\
\text { hospitalization room }\end{array}$ & $\begin{array}{c}\text { Design rooms which are suitable for } \\
\text { presence of family during } \\
\text { hospitalization }\end{array}$ \\
\hline $\begin{array}{l}\text { need to safety in presence of } \\
\text { family during medical } \\
\text { process }\end{array}$ & $\begin{array}{l}\text { Make some facilities to } \\
\text { presence of parents in } \\
\text { hospitalization room }\end{array}$ & $\begin{array}{l}\text { Design some rooms which are } \\
\text { suitable for presence of family, } \\
\text { enhance intimacy by doctors and } \\
\text { nurses to calm sick children in } \\
\text { absence of parents }\end{array}$ \\
\hline $\begin{array}{l}\text { need to communication with } \\
\text { other sick children }\end{array}$ & $\begin{array}{c}\text { Make some facilities and } \\
\text { public area for meeting and } \\
\text { communication among } \\
\text { children }\end{array}$ & Build a pubic area \\
\hline $\begin{array}{l}\text { need to presence of parents } \\
\text { and other sick children } \\
\text { simultaneously }\end{array}$ & $\begin{array}{l}\text { Using multi-bed room to social } \\
\text { communication among } \\
\text { children }\end{array}$ & $\begin{array}{l}\text { Build some places to meet parents in } \\
\text { addition to other hospitalized children }\end{array}$ \\
\hline
\end{tabular}

\section{REFERENCES}

Hojjat, Isa, Ebneshahidi, Marjan. (2011). Redefines of hospitalization environments in children hospitals based on evaluating and analyzing of children's need with the approach of fear decreasing of environment, fine art journal, architecture and urban planning: 13. 
Ghorbani, Motahareh, Enayati, Bahram. (2015). Physical Environment Components Redefining to design Children's Hospital. Human, Architecture, Civil Engineering and City International Conference, Tabriz. Balayan, Masroub. (1991). Children psychology in simple language. Tehran. Mashal Publication Khana, Goriha. (2003). Stress from psycho-physical treatment collection. Translation by Shaghayegh Ghandehari. Tehran. Peydayesh publication.

Shmitt, Marcus, (2001). Children's fear: how children can overcome small and big fears: translation by Leila Lafezi, Tehran, Publication of PTA.

Del Nord, Romano. 2006. Environmental Stress Prevention in Children’s Hospital Design. Motta Architettura Srl .Milan.

De Vos, Fiona (2006), Building a Model of Holistic Healing Environments for Children's Hospital: With Implications for the Design and Management of Children's Hospitals, PhD Thesis, The City University of New York.

Barati, Naser. (2011). Motivation understanding in controlled environment and influence of this on gender. Bagh Nazar Quarterly, number 7, the eighth year.

Pakzad, Jhamshah. (2012). Psychological alphabet of environment for designers. Tehran. Arman Shahr Publication. The first edition.

Mosaddeghzade, Alimohammad. (2003). Adapting investigation of patients' rights prism in some selected countries and Iran, Number 3, the fifth year.

Ulrich, Roger, (1889) Effects of interior design on wellness, JournalOf Health Care Interior Design, p97109. 